\title{
Peripheral Interventions for Painful Stump Neuromas of the Lower Limb
}

DOI:

10.1097/AJP.0000000000000533

\section{Document Version}

Accepted author manuscript

Link to publication record in Manchester Research Explorer

\section{Citation for published version (APA):}

Poyntz, S. A., Dalal, M., Hacking, N., \& Fowler, S. (2018). Peripheral Interventions for Painful Stump Neuromas of the Lower Limb: A Systematic Review. Clinical Journal of Pain. https://doi.org/10.1097/AJP.0000000000000533

\section{Published in:}

Clinical Journal of Pain

\section{Citing this paper}

Please note that where the full-text provided on Manchester Research Explorer is the Author Accepted Manuscript or Proof version this may differ from the final Published version. If citing, it is advised that you check and use the publisher's definitive version.

\section{General rights}

Copyright and moral rights for the publications made accessible in the Research Explorer are retained by the authors and/or other copyright owners and it is a condition of accessing publications that users recognise and abide by the legal requirements associated with these rights.

\section{Takedown policy}

If you believe that this document breaches copyright please refer to the University of Manchester's Takedown Procedures [http://man.ac.uk/04Y6Bo] or contact uml.scholarlycommunications@manchester.ac.uk providing relevant details, so we can investigate your claim.

\section{OPEN ACCESS}


The Clinical Journal of Pain Publish Ahead of Print

DOI:10.1097/AJP.0000000000000533

Peripheral interventions for painful stump neuromas of the lower limb: a systematic review

\section{Authors:}

Stephanie Alexandra Poyntz MBChB Hons, Milind Dalal FRCS (Plast), Nicholas Hacking FRCA, Stephen Fowler MD FRCP

\section{Acknowledgments:}

Dr Fergus Jepson MBChB, Consultant in Amputee Rehabilitation, Specialist Mobility Rehabilitation Centre, Preston, UK

\section{Correspondence}

Dr Stephanie A Poyntz

Personal address:

(Until August 2016)

Dr Stephanie A Poyntz

Lancashire Teaching Hospitals Foundation

9 Old Wickham Lane

Trust

Haywards Heath

Sharoe Green Lane

West Sussex

Preston

RH16 1UP

PR2 9HT

UK

Mobile: 07872608945 
Email: Poyntz19@doctors.org.uk (Stephanie Poyntz)

stephen.fowler@manchester.ac.uk

\section{The authors declare no conflict of interest}

Academic Supervisor:

Dr Stephen Fowler

Respiratory and Allergy Research Group

Education and Research Centre

Wythenshawe Hospital

Southmoor Road

Manchester

M23 9LT

United Kingdom

Telephone: +441612915864

Alternative Telephone: +44 1612915873 (Alex Sadler)

Fax: +44 1612915730

No funding was received from the National Institute of Health, Wellcome Trust, Howard Hughes Medical Institute or any others. 


\section{Abstract}

Objectives: Painful stump neuromas in lower limb amputees are a significant burden on a person's quality of life due to interference with wearing prostheses and therefore the ability to walk. Treating painful stump neuromas is a challenge perhaps reflected by the lack of clinical guidelines both in the United Kingdom and internationally. Methods: A systematic review was conducted to evaluate the efficacy of all treatments tried in the management of symptomatic neuromas in the lower limb amputation stump in order to establish whether one treatment is superior. Results: Twenty-two studies were included in the final review which examined 14 different treatments both surgical and nonsurgical. Results showed that no single treatment showed superiority. Discussion: The four treatments that showed most promise included targeted nerve implantation (TNI), traction neurectomy, nerve-tonerve anastomosis and perineurial gluing. The short follow-up times and small sample sizes of the studies highlighted the need for more robust clinical studies.

Key words: stump pain, neuroma, treatment, amputation, management 


\section{Introduction}

Post-amputation pain (PAP) is a disabling condition which can have a significant impact on a person's quality of life due to its unpleasant symptoms and its interference with the ability to wear prostheses. ${ }^{1}$ It is a particular problem for patients with leg amputations who often require prostheses to aid walking. Stump pain, a sub-type of PAP, is caused by a number of pathologies including vascular insufficiency, bony spurs, skin damage and neuromas.

A neuroma describes the bulbous tumour of a nerve ending that occurs following traumatic transection (such as during the primary amputation), or following traction-related nerve damage. Following dissection, the nerve fibre undergoes Wallerian degeneration distally and when re-growth occurs, the axon fibres and new Schwann cells grow in a disorganised fashion, colloquially termed "sprouting". ${ }^{2}$ This sprouting can result in a cluster of cells (the neuroma) at the distal end of the nerve stump which subsequently has the disposition to discharge spontaneously due to increased mechanical- and chemosensitivity. ${ }^{3}$ It is often this ectopic electrical activity that leads to the sensation of the electric shocklike pain of which patients complain.

Treating painful stump neuromas (PSNs) is challenging. The National Institute of Health and Care Excellence (NICE) provides clinical guidelines for pharmacological and interventional management of neuropathic pain, ${ }^{4}$ however, the guidelines are based on studies involving participants with different chronic pain syndromes and whether these studies involved patients with PSN is unclear. ${ }^{5-7}$ Looking beyond the United Kingdom, the only guidelines from the American Pain Society is for opioid treatment in non-cancer pain and interventional management for back pain. No European guidelines for management of PSN could be identified. ${ }^{8}$ Although there are no clinical guidelines for the management of PSN, attention has turned to recognising different pain mechanisms (peripheral, spinal and supra-spinal) involved in PAP and that each mechanism may require a different treatment modality. ${ }^{1}$ Targeting PAP therefore with a multi-treatment approach is now being considered as the way forward and may even lead to the emergence of clinical guidelines for this condition. ${ }^{1}$ 
In the Western world, amputation of the limb is most commonly due to vascular pathology $(82 \%$ of all limb amputations) with trauma being the second most common cause. ${ }^{9}$ The incidence and prevalence of stump pain is not well documented and there is discrepancy in the figures that are available. One long-term study of patients with leg amputations reported that $64.5 \%$ of participants experienced stump pain ${ }^{10}$ compared with $21 \%$ reported by a different cohort study. ${ }^{11}$ Although the risk factors for the development of painful stump neuromas has not been studied in great detail, there is emerging evidence that pre-operative pain including its intensity and duration appear to have a role. ${ }^{11,12}$ Stokvis and colleagues identified several prognostic factors for inadequate pain relief following surgical management including unemployment, smoking and ineffective diagnostic nerve blocks. ${ }^{12}$

We have reviewed the literature regarding treatments that target peripheral mechanisms of PSN in an aim to alleviate pain. Peripheral interventional treatments of PSN can be broadly categorised into surgical and non-surgical, with non-surgical being sub-categorised into neuroablative and nonneuroablative. The surgical treatments reviewed in this work are traction neurectomy, nerve implantation and nerve-to-nerve anastomosis. The non-surgical treatments reviewed include injection therapies, radiofrequency, cryoablation and shock-wave therapy. In this review, we ask the question, "Is there evidence to guide treatment for symptom relief in painful stump neuromas of the lower limb? If so: what is the best choice of therapy?'

\section{Materials and Methods}

\section{Search Strategy}

A literature search was carried out using MEDLINE (1946-January 2016) and Embase (1974 January 2016), and the Cochrane Library. A broad search was conducted using MeSH headings and free-text including the terms "neuroma*", "pain*" and "treatment". MeSH headings were examined for other relevant terms relating to the various techniques used in painful neuroma management and journal references were hand-searched to identify additional articles; forward searching also took place. Following screening of titles and abstracts, experimental studies and those involving exclusively 
Morton's (intermetatarsal) neuroma or acoustic neuroma were excluded. Due to the scarcity of high quality data supporting the interventions, a narrative review of data from lower evidence studies has been included.

\section{Article Selection}

This review focuses on peripheral interventional treatment of PSN of the lower limb. . Phantom limb pain and other causes of stump pain were not part of this study because the authors felt that these topics have been discussed in other review articles ${ }^{1,3}$. Articles which examined pharmacotherapy, complementary therapy or pain treatments which targeted body sites other than peripheral were not included in the review. Papers that looked exclusively at upper limb neuromas and digital neuromas were also excluded. Once all the papers were identified, we considered whether a meta-analysis could be performed.

\section{Results}

The search returned 470 records; there were no results found in the Cochrane Library. Following the application of exclusion criteria and removal of duplicated material, 100 abstracts were screened and 65 papers excluded for being irrelevant (non-peripheral treatment, non-interventional treatment, phantom pain only). Following back and forth hand-searching of references of these 35 papers, a further seven papers were identified as being potentially relevant including one which had yet to have MeSH headings mapped to it. These 42 papers were read in full and 20 were excluded as they were deemed inappropriate (narrative reviews, digital neuromas). Twenty-two studies were included in the final review (see tables 1,2,3) with an equal number of papers focusing on operative (11) and nonoperative (11) management. Looking at the quality of evidence in the literature found, there were 14 case series/reports, six cohort studies (all without control groups), and two randomised control trials (RCTs). Fourteen different peripheral interventional techniques have been researched including seven different surgical techniques.

The most prevalent pain measurement tool was the Visual Analogue Scale (VAS) with 13/22 studies using this rating scale. Other papers used different pain measurement tools including 3 and 4-point scales, the McGill pain questionnaire and the Pain Rating Scale (PRS). Pain scales such as the Leeds Assessment of Neuropathic Symptoms and Signs (LANSS) and painDETECT which identify 
neuropathic pain from nociceptive pain were not used in any study in this review.

The average follow-up period where final assessment took place ranged between 3 and 82 months ( median $=12$, mode $=6$, mean $=18.9$ months $)$. Sehirlioglu and colleagues ${ }^{19}$ demonstrated that neuromas take on average 12 months to form however, only 13/22 studies had an average follow-up time of more than 12 months. All papers that evaluated surgical techniques diagnosed neuroma on the basis of clinical symptoms and none used radiological imaging either pre-operatively or during followup. Eight papers looked at whether patients had more comfort in wearing their prosthesis after treatment but this was only descriptive and did not use any quantitative form of measurement. Only three papers considered quality of life and again, these results were only descriptive. With regards to meta-analysis, the heterogeneity of the studies was too great to be able to pool the data and make a conclusion about the treatment effect.

\section{Diagnosing painful neuroma}

All studies in this review diagnosed the presence of a painful neuroma based on the patient's subjective history of localised tenderness including reproducible pain on palpation in the form of Tinel's sign. In addition to this, the finding of a sensitive, palpable lump in the proximity of a nerve or scar tissue was deemed to be a positive indicator of a painful neuroma. Twelve studies used a diagnostic block with lidocaine as a positive diagnosis. Seven non-surgical papers involved ultrasound to aid diagnosis and treatment, but only one paper used ultrasound in the follow-up..$^{13}$ For the studies examining surgical techniques, only two ${ }^{18,23}$ mentioned sending neuromas for histological examination and only one of those two studies confirmed that specimens were true traumatic neuromas. ${ }^{23}$ The remaining surgical papers relied on the "operative identification" of neuroma.

\section{Use of radiological imaging}

Seven papers used ultrasound to aid diagnosis of a painful neuroma and one paper used sonography as part of follow-up. There have been no studies analysing the sensitivity and specificity of ultrasound in the diagnosis of traumatic neuromas, nor in its usefulness in follow-up, however a meta-analysis examining diagnostic accuracy of ultrasound in Morton's neuroma demonstrated that it was superior to magnetic resonance imaging. ${ }^{47}$ 


\section{Surgical therapies}

Surgical therapies constitute the majority of published papers on treatments for PSN. A number of techniques have been researched including traction neurectomy, vein implantation, burial techniques (either into bone or muscle), perineurial adhesis and nerve-to-nerve anastomosis.

\section{Traction neurectomy}

Only two case series have been published on the outcomes of a surgical method that is most commonly used in clinical practice when treating symptomatic stump. ${ }^{15,19}$ Traction neurectomy is the technique of gently pulling on the affected nerve before dissecting it proximally and allowing the tension to retract the severed nerve back up into soft tissue with the hope that the absence of pressure on the distal end of the nerve will be sufficient to prevent neuroma formation. The authors' experience is that the method of nerve cutting can vary according to clinician's choice. Diathermy, ligation and cutting with a blade have all been used. Sehirlioglu and colleagues (Table 1) reviewed 75 patients who had developed painful neuromas following lower limb amputation due to landmine explosions. All patients underwent traction neurectomy (unknown method of transection) and remained pain free at follow-up at mean 2.8 (range $0.5-6.0$ ) years. These results differ from those reported by Pet et al. (Table 1) who reviewed 38 lower limb amputees available to follow-up after treatment, although the exact method of dissection of the nerve is not reported. Pet and colleagues found that only $58 \%$ were pain free at follow-up which was on average at 37 months (11-91 months). This study found that gender was a significant prognostic factor for treatment outcome with males being more likely to have treatment failure. However, a large prospective follow-up study by Stokvis et al. ${ }^{12}$ showed no significant correlation between gender and treatment outcome. Pet et al. provide a thorough discussion of the limitations of their study; the largest limitations being the level of evidence of the study design, high numbers lost to follow-up and confounding factors such as concomitant bony spurs making interpretation of results difficult. Additionally, the outcome variables were somewhat limited with patients being categorised as either 'pain free' or having 'pain recurrence/persistence'. The lack of using a pain measurement tool such as the VAS means it is hard to compare with other studies.

\section{Vein implantation}


Following on from experimental studies which have suggested that implanting transected nerves into veins can produce more organised re-growth and reduce neuroma formation compared to controls, Koch and colleagues (Table 1 ) carried out two retrospective case series $(n=23 \text { and } n=8)^{20,22}$. All patients were experiencing moderate or severe pain based on a 4-point scale of their painful neuromas of superficial nerves before they underwent excision of the neuroma followed by implantation into a superficial vein. There were two techniques involved: implantation via venectomy (end-to-side) or where the vein was transected, with the nerve inserted and sutured into it (end-to-end). Eleven out of 23 and four out of eight patients were pain free at follow-up, the mean being 26.5 and 17.0 months respectively. Pet and colleagues demonstrated that neuroma excision alone with traction neurectomy provides slightly better outcomes within the same time frame so it is difficult to assess whether it is the vein implantation or the actual excision of the neuroma that is the determining factor in this respect. This method of vein implantation is only feasible with superficial nerves and veins as using larger, deeper veins would increase the risk of thrombosis.

\section{Muscle implantation}

Ducic and colleagues ${ }^{18}$ (Table 1) performed a retrospective cohort with no control group on a number of upper and lower limb amputees which investigated the outcome of nerve implantation into muscle as previously described by Dellon and colleagues. ${ }^{35}$ This appears to be the first cohort study using this technique that involves lower limb amputation stumps. Twenty-one amputees, including three patients with above knee amputation (AKA) and 12 patients with below knee amputation (BKA) underwent this surgical procedure. In order to eliminate concomitant pathologies that could interfere with data interpretation, patients with other causes of stump pain were excluded. The mean VAS was significantly reduced from 8.04 to 1.07 post-operatively with 11/21 (52\%) being pain free at follow-up which was at mean (range) 22.8 months (9-39 months). However, as with all studies that measure pain, there is likely to have been a degree of response bias.

\section{Comparing muscle and vein implantation}

Vein implantation was compared with muscle burial by Balcin and colleagues (Table 1) who conducted a randomised double-blinded trial (each group $n=10$ ) to look at which surgical method provided greater pain improvement. ${ }^{17}$ Twenty patients with traumatic painful neuromas of the lower 
limb (but not amputees) were allocated to undergo neuroma excision followed by one of the two treatments; all patients completed the follow-up period of 12 months. Pain improvement was measured using two tools: the McGill questionnaire and the VAS. In comparing pre-and post-operative outcomes, only the nerve-into-vein cohort achieved significance in reducing VAS scores $(\mathrm{p}<0.01)$. Comparing the outcomes of the two procedures at final follow-up, the nerve-into-vein group demonstrated improvement in pain in one pain measurement tool (McGill, $\mathrm{p}<0.05$ ). The patients included were those whose neuromas developed in cutaneous nerves following orthopaedic surgery (unspecified, not amputations). The exclusion criteria were strict so that patients with previous operative neuroma management, diabetes, autoimmune disease, cancer and peripheral arterial disease were not considered; however, the two groups were comparable in baseline characteristics. Despite all patients completing follow-up, it could be argued that this was not a long enough period as one study has shown that the average length of time for neuroma formation to occur is around 12 months. ${ }^{19}$ Although this study demonstrated that neuroma excision followed by vein implantation reduces pain, we also know that traction neurectomy has the potential to reduce pain. ${ }^{15}$ Studies comparing traction neurectomy and vein transplantation would therefore be useful in determining which provides the better outcome for the longest amount of time. Finally, despite being a randomised trial, this was still a small study which did not include stump neuromas and therefore it is not possible to generalise the results.

\section{Muscle burial vs bone burial}

Chiodo and colleagues (Table 1) explored whether there was a significant difference in pain reduction when comparing burial of the proximal nerve stump into bone and into muscle. ${ }^{21}$ Having excluded patients with complex regional pain syndrome, 27 patients with superficial peroneal neuromas were analysed in a cohort which examined their pain relief using VAS, percentage of pain relief and a 5point pain relief scale. Patients were divided into two groups to receive the two treatments. Four patients who had ineffective pain relief with muscle burial were then put into the second group. Appropriate analysis of results demonstrated that there was a significant difference in VAS and perceived pain relief with burial into bone providing more pain relief compared to burial into muscle. However, these results are confounded by the swapping of patients from one group to another, by 
concomitant orthopaedic procedures and by a dramatically shorter average follow-up for the bone implantation group. This study also involved non-stump neuromas so once again, the results cannot be generalised.

\section{Nerve anastomosis}

Originally described by Samii and colleagues in $1981^{36}$ nerve-to-nerve anastomosis has been given a number of names including "centro-central anastomosis" and "centro-central short circuiting" (CCSC). The technique, which involves separating the individual fascicles of a nerve stump and anastomosing the ends together in an attempt to prevent neuroma growth, has previously been researched for its use for treating Morton's and digital neuromas. Only two low evidence papers have examined the effectiveness of the technique in treating painful amputation stump neuromas. In 1993, Barbera and colleagues wrote a case series on 22 patients with lower limb amputations secondary to peripheral vascular disease who were followed-up on average at 15 months (12-24). ${ }^{23}$ Pain sensation (no measurement tool mentioned) before and after the procedure and the ability to wear a prosthesis was documented. Twenty-one out of 22 patients reported to be free of neuroma-type pain at follow-up with 18 being able to wear their prosthesis full-time; one patient developed another symptomatic neuroma within 4 months. Although this is very weak evidence, the follow-up time was arguably long enough to allow formation of a recurrent neuroma and the results are encouraging. However, compared to traction neurectomy, this procedure appears to be more complex, requiring the use of a particular skill set and the ability to perform microsurgery, thus making the operation more complex and time-consuming. Bouroumand and colleagues has looked at the same procedure in a more recent small cohort of eight patients who were followed up over a longer period of time of 6.8 years (1.5-12 years) ${ }^{14}$. VAS scores "at worst" were used for statistical analysis using Wilcoxon matched-paired test but due to the small sample and nonlinear distribution, the significance achieved cannot be interpreted. Despite this, results did show a reduction in the VAS from $7.75 \pm 1.28$ to $2.25 \pm 1.07$. Limitations of this study included the lack of a control group and the confounding factor that the anastomosis was then buried into muscle. It is therefore difficult to assess the impact of this intervention on prevention of neuroma-pain with that of CCSC. 
In a more complex procedure, Pet and colleagues looked at a technique called 'targeted muscle implantation' (TNI) in a retrospective case series of 35 patients. ${ }^{16}$ This procedure involved joining the nerve stump to a motor nerve which has been denervated from its source; this method is based on the theory that proximal nerve axons will arborise along the motor nerve branches rather than form a neuroma. In this case series, Pet et al. divided the cohort into two groups: those that had TNI as a primary procedure at time of amputation (no neuroma) and those that had TNI as a secondary procedure to treat an already established symptomatic neuroma. For those that had TNI as a primary procedure, 11/12 (92\%) were free from neuroma pain at follow-up (22 months, range 8-60). For those who had secondary TNI, 20/23 (87\%) were free of neuroma pain at follow up (22 months, range 4-72 months). The authors discuss the limitations of the study in good detail including the issue of transfer bias with $24 \%$ of eligible patients being lost to follow-up and issues with concomitant pathologies that could have caused the stump pain rather than the neuroma; on the other hand Pet et al. did not exclude patients with bony spurs, and treated neuroma pain as an all-or-none phenomenon which does not reflect the complexity of neuropathic pain.

\section{Perineurial adhesis}

This single case series by Martini and colleagues followed on from an experimental study which demonstrated that gluing the perineurium over surgically shortened fascicles prevented axon sprouting compared with ligation and capping. ${ }^{24}$ Thirty-six patients with amputation stump neuromas (including digital neuromas) underwent the procedure described above. At follow-up, mean (range) 17 months (4-43), 28/36 were pain free. Despite these results, no further clinical studies have since looked at this technique nor do any narrative reviews give explanation as to why this technique has not been further explored. ${ }^{2,37,38}$

\section{Non-surgical methods: neuroablative therapies}

\section{Phenol injections}

Although phenol and other sclerosing injections have been used in the management of chronic pain in general, only one paper has followed-up the effects of ultra-sound guided phenol injections in the specific management of painful amputation stump neuroma. ${ }^{27}$ Eighty-two amputees (71 lower limb) received either 1, 2, or 3 phenol injections into their stump neuromas. Participants rated the quantity of 
their pain (VAS) and character of the pain after each treatment and finally at 6 months. Although three injections were planned for each participant, there was a high drop-out rate at each stage. The authors analysed this confounding factor and found no negative reasons for this other than the fact that the initial treatment had provided adequate pain relief; each group was homogeneous in baseline characteristics. Statistical analysis was therefore applied to three groups according to the number of injections received. Fifty-two patients were available at the 6-month follow-up. The overall median VAS score was reduced from $10 \pm 1.5$ to $3 \pm 2.6$ with significance achieved for each individual group. Although no participants were left entirely pain free, 20/52 (39\%) reported being almost pain-free and no patients experienced worse pain compared to before treatment. Interpretation of the results was complicated by the poor participant compliance and the largest issue with the study was relating to side-effects. Ten percent of patients, $8 / 52$, (reported as $5.1 \%$ based on total number of injections) experienced minor complications such as painful oedema, local infection and painful myopathy and two patients had major complications including soft-tissue necrosis.

\section{Alcohol injections}

Only one small case series of two patients was identified which examined the use of sclerosing alcohol injections in the management of PSN. ${ }^{26}$ The first patient (BKA) with a VAS score of $10 / 10$ due to a common peroneal nerve neuroma. Following the first injection, he remained pain free for 3 months before the pain subsequently returned to 7/10. A second injection reduced his pain to $3 / 10$ but he was not followed-up beyond 3 months to see if the pain recurred. The second patient (AKA) with a painful sciatic neuroma (VAS 8.5). His reduction in pain was slightly less pronounced but still decreased to 4/10 for 3-months until it returned to 7/10 where he was given a second injection to good effect. Again, the lack of follow-up meant that cumulative effects of alcohol injections are unknown. Although this is only a case series of two, it seems as though the effects of alcohol injections are very short lived.

\section{Cryoablation}

Experimental models have demonstrated that following Wallerian degeneration post cryoablation, axon re-growth is more organised thus reducing the chance of neuroma formation. The theory is that preservation of the perineurium and epineurium which is not destroyed during cryotherapy helps this 
process due to neuroplastic remodelling. ${ }^{39}$ However, this theory is yet to be proven. Following on from studies that have demonstrated that Cryoprobe therapy has successful in treating a variety of neuropathic pain syndromes, ${ }^{40,41}$ Caporusso and colleagues examined the clinical efficacy of cryoablation in treating painful neuromas in a prospective cohort study $(n=20) .{ }^{29}$ Although the study reported significance in their success rate with 12 patients being pain free at one year, the majority of the neuromas studied were in fact intermetatarsal (Morton's) neuromas. There were 3 nonintermetatarsal neuromas (all cutaneous nerves of the lower limb) but the results for these neuromas were not separated from the rest. Additionally, none of the patients were amputees. Reporting a similar success rate to that of simple surgical excision, the authors stated that a randomised trial comparing the two techniques was in progress although this has not been published to date. Only one pilot study $(n=10)$ has looked at cryoprobe therapy for the treatment of PSNs in amputees which was reported in a letter. ${ }^{28}$ Although $9 / 10$ patients reported pain improvement at 3 months, only 3 patients were still experiencing pain relief 1 year following the procedure whilst 8/10 reverted back to pre-treatment pain levels and 1 patient reported pain worse than before.

\section{Non-surgical methods: non-neuroablative therapies}

\section{Steroid injections}

The literature search only identified one cohort study describing the use of steroid injections in PSN. In 14 patients diagnosed with PSN using the patient's history, reproducible pain, a palpable mass and ultrasound, Kesikburun and colleagues administered a single sonographically guided steroid injection into the neuroma. ${ }^{30}$ Mean VAS scores reduced from 7.6 to 3.5 at 6 month follow-up, although three patients underwent surgical management in this time and were considered to have failed treatment. The authors acknowledged the serious limitations of this study including the lack of comparison group and short follow-up time. However, by grouping the patients into those who had greater than or less than $50 \%$ reduction in pain, they suggested a prognostic factor: those who had experienced symptoms for longer were less likely to get as much benefit from the treatment. ${ }^{30}$

\section{Extracorporeal shock-wave therapy}

Extracorporeal shock-wave therapy (ESWT) has been used to treat pain in a number of musculoskeletal conditions including epicondylitis and calcific tendonitis of the shoulder. However, 
the literature reporting results of this technique have low quality evidence and the results have been variable. $^{42}$ The physiological effects of ESWT are still theoretical but researchers believe that pulsations can cause tissue breakdown and scar re-modelling; this can allow any tension that may be on a neuroma to be released thus reducing ectopic activity and pain. Only one paper was found in the literature search which explored ESWT in treating PSNs in a controlled trial. ${ }^{13}$ Following serial enrolment of thirty amputees (digital, upper limb and lower limb), Jung and colleagues randomised (details of randomisation not specified) the participants to receive either a ESWT once a week for 3 weeks or transcutaneous electrical nerve stimulation (TENS) with pharmacotherapy (details not specified). Pain before and after treatment was measured using a number of tools including the VAS, McGill pain questionnaire and pain rating scale (PRS); neuroma size was also measured. Final assessment at three months revealed that both treatments showed a significant difference in pain reduction across all pain scales. The EWST group, however, achieved greater mean pain reduction most apparent using the PRS. No patients were pain free at the end of the study but there were no complications and no patients experienced worse pain. The study also revealed no significant change in the neuroma size. Although this study suggests that ESWT performs better than conventional TENS and pharmacotherapy, there were several limitations, namely the short follow-up time, small sample size and the variation in the number of different amputation levels. There was also no mention of ethical approval. It would have useful to have a few more details such as the length of time between amputation and neuroma symptoms and how the authors accounted for other factors such a simultaneous PAP unrelated to the neuroma. It may also be useful to compare EWST against a number of other treatments used for treating PSN.

\section{Radiofrequency treatments}

Another technique that is increasingly being researched in the treatment of a variety of chronic pain conditions is radiofrequency (RF). ${ }^{43}$ There are two broad classes of RF: ablative thermal lesioning and pulsed RF which is generally conducted at lower temperatures and is not associated with gross tissue destruction. RF thermal lesioning tends to be practices in two forms: short bursts of relatively high energy as in surgical diathermy and the more prolonged, controlled application of relatively lowenergy RF. Four low evidence papers reporting the effects of peripherally administered pulsed 
radiofrequency on patients with PSN were identified (Table 4). West and colleagues described a case series of four patients (three post-AKA and one above elbow amputee) who were experiencing significant stump neuroma pain and were completely unable to wear their prosthesis. ${ }^{33}$ Following treatment with pulsed radiofrequency delivered to the neuroma percutaneously, all 4 patients experienced complete pain relief lasting between 4-6 months and were able to tolerate the wearing of their prosthesis. Two patients' pain returned by 6 months however it was less severe than before treatment. The same benefit was observed in case reports by Wilkes and colleagues, ${ }^{34}$ RestrepoGarces and colleagues ${ }^{32}$ and Kim and colleagues ${ }^{31}$ but similarly, their follow-up only lasted 6 months. Although these case reports report benefit with pulsed radiofrequency, their low quality study design and short follow-up mean that further research is needed before we can determine whether pulsed radiofrequency really is an effective treatment in the management of PSN.

\section{Coblation}

Coblation (cold ablation) describes a form of RF lesioning used in ENT surgery which involves applying radiofrequency through a conductive solution; this creates radical species whose energy has the ability to cause tissue breakdown without causing thermal damage. Zeng and colleagues believe that technique may have a role in treating PSN and have reported one case of a patient with AKA with a painful femoral nerve neuroma who reported a decrease of his pain by $80 \%$ which lasted 6 months until the follow-up period ended..$^{25}$ Considering this is the first reported case of using coblation in PSN, not much can be inferred from this observation but it contributes to the continuing myriad of treatments investigated for this complex condition.

\section{Complications}

Out of all the 11 surgical papers, three reported that no complications occurred. ${ }^{14,18,24}$ (Table 1), six papers reported complications of infection, wound dehiscence and recurring pain..$^{15,17,19,20,21,23}$; in two papers, there was no mention as to whether there were any complications. There was no mention of any complications in three of the non-surgical papers ${ }^{30,31,34}$, six reported that there were no complications ${ }^{13-25,26,29,32,33}$, and two papers reported complications ${ }^{27,28}$ which included infection and tissue necrosis with phenol injections and worse pain with cryoablation (Tables 2-4). 


\section{Discussion}

\section{Statement of findings}

Although some treatments have shown promise, this review demonstrates that there is a lack of evidence to quide the peripheral management of lower limb PSNs. Within this review, Targeted Nerve Implantation demonstrated the most impressive results. Although very low level evidence, traction neurectomy also provided good results. The remaining two techniques that have shown promise are nerve-to-nerve anastomosis and perineurial gluing.That so many different treatments have been explored for the management of painful neuromas demonstrates that not one single treatment modality is superior. However, this conclusion is based on a review of studies that either have a small sample size or a short follow-up time. We therefore call for more research, both surgical and non-surgical, with greater numbers of participants and longer follow-up times.

\section{Discussion of findings}

Stump neuromas are common sequelae of limb amputation but not all neuromas are painful. When a stump neuroma does become symptomatic, it is a significant cause of morbidity and therefore finding a treatment that is effective for a long period of time with few side-effects is the main goal of treatment. Hsu and colleagues described the pathophysiological basis of post-amputation pain as involving peripheral, spinal and supra-spinal mechanisms and highlighted the importance of therapy being individually tailored and mechanism-based. ${ }^{1}$ Stump pain, whether due to neuroma or a bony spur, is predominantly recognised as being a peripheral mechanism and therefore it can be argued that treatments should primarily be peripherally focused. Despite this, the current evidence for peripherally-based treatments is poor. Furthermore, before a superior peripheral interventional treatment has been established, new research into treating spinal mechanisms in the management of PSN is taking place. ${ }^{46}$

Studies looking at the effectiveness of treatments for PSNs are extremely difficult to execute due to the subjective nature of pain and other qualitative-based outcomes such as quality of life and ability to perform activities of daily living (ADLs) . Neuroma pain is extremely variable in terms of intensity, frequency and duration; it is often worse when the patient is using a prosthesis. Patients can fjnd it hard to differentiate between the sub-types of stump pain and between nociceptive and neuropathic 
pain. Differentiation between nociceptive and neuropathic pain is possible through using tools such as painDETECT and LANSS. Other pain assessment toolsassess the effects of pain on activities of daily living (McGill),the nature (character) of the pain as well as the intensity, and those that simplify pain into a 10-point scale (VAS). A phenomenon as complex as PAP requires complex measurement tools however, this becomes very challenging when interpreting the results and comparing studies. It is important that future studies try and standardise the use of pain measurement tools.

\section{Strengths and limitations of this critical appraisal}

Despite there being a number of narrative reviews on the subject of neuroma pain and is management $1,2,37,38,45,46$ we believe that ours is the first attempt at a systematic review., albeit with a number of limitations. It is difficult to know whether all potential papers for review have been identified; publication bias will certainly have played a role. For example, there was one publication that was not found in the literature search despite it involving PSN management as the MeSH heading included "phantom pain" and "stump pain" was only mentioned in the body of the text.

The original research question was primarily concerned with lower limb stump neuromas because there are different considerations with regards to achieving good pain relief compared with non-stump neuromas and upper limb neuromas. As the lower limb is involved with weight-bearing, most amputees of this body part require the use of a prosthesis in order to ambulate. Due to the mechanically sensitive nature of neuromas, wearing a prosthesis is often problematic, arguably more so than the upper limb amputee with a symptomatic neuroma. Given this consideration, there was some uncertainty as to whether to include research papers that involved a mixture of upper limb and lower limb stump neuromas as well as papers that involved both amputation neuromas and nonamputation neuromas. It was decided that papers looking exclusively at digital and upper limb stump neuromas would be excluded. This decision was based on a number of reasons. Firstly, the volume of literature that looks at exclusively at upper limb neuromas is vast and would detract away from the original research question; subsequently the authors believe that digital neuromas warrant special consideration due to the complex nature, function and size of hand anatomy. Similarly, the review was limited in such that it only focused on one type of amputation pain. It was felt that broadening the scope to include management of phantom pain or other causes of stump pain would make the paper 
too long. The decision to focus on a fairly narrow topic was because other literature has explored postamputation pain as an entire phenomenon. ${ }^{1}$

Another limitation of this review relates to the level of evidence of the literature. The ideal studies to answer the research question would have been RCTs and cohort studies with control groups, however, the level of evidence of literature in this review was weak and therefore any conclusions will be tenuous. In order to write a good quality systematic review, there needs to be a sufficient number of studies of sound methodology looking at the same treatment method. Low level evidence papers could have been excluded but this would have left eight papers with no more than two studies looking at the same treatment. In addition to the variety of study designs, the actual number of treatments being researched as well as their different outcomes being measured makes meta-analysis extremely difficult and the results of this study had to be presented in a non-statistical format.

\section{Other potentially important outcomes}

The authors appreciate that looking exclusively at pain scores is simplistic and not reflective of the complexity of this clinical condition. Other outcomes that were not analysed but are important to consider when evaluating the benefit of painful stump neuroma treatment include quality of life, the ability to perform ADLs, and the ability to wear a prosthesis. It was felt that the studies in this review did not measure these other outcomes in enough detail to be able to draw any meaningful conclusions.

\section{Recommendations for practice}

We suggest the use of radiological imaging as part of the clinical work-up in diagnosing the cause of stump pain: ultrasound to idenitify any neuroma and xrays to identify bony spurs. This allows concomitant pathology to be identified and treated adequately. We also recommend follow-up ultrasound at three and 12 months in patients who have undergone excision and have recurrence of symptoms to objectively demonstrate whether the neuroma has recurred. Pet and colleagues observed that stump neuromas are most frequently managed by traction neurectomy in clinical practice and the authors of this review note the same. ${ }^{15}$ In the knowledge that there are many patients regularly undergoing revision surgery, it is unknown why more robust clinical trials have not taken place. The need for better documentation on the incidence and prevalence of PSNs as well as more research into these treatment methods is long overdue. 
The authors of this study suggests that any clinical study in this domain which takes place from now on should have a minimum follow-up period of 12 months with follow-up being performed at the same time-points. There should be explicit detail of how the procedure was performed and how the pain was measured with standardisation of pain scales and above mentioned outcomes; finally a comparison group would be of benefit in determining the effect of the treatment.

\section{References}

1. Hsu E, Cohen SP. Postamputation pain: epidemiology, mechanisms and treatment. J Pain Res $2013 ; 6: 121-136$.

2. Rajput K, Reddy S, Shankar H. Painful neuromas. Clin J Pain 2012;28:639-645

3. Flor H, Nikolajsen L, Staehelin JT. Phantom limb pain: A case of maladaptive CNS plasticity. Nature Rev Neurosci 2006; 7(11): 873-881

4. National Institute for Health and Care Excellence (2013) Neuropathic pain in adults: pharmacological management in non-specialist settings. Clinical guidelines (CG173)

5. National Institute for Health and Clinical Excellence (2011) Deep brain stimulation for refractory neuropathic pain (excluding headache). NICE interventional procedure guidance (IPG382)

6. National Institute for Health and Clinical Excellence (2013) Percutaneous electrical nerve stimulation for refractory neuropathic pain. NICE interventional procedure guidance (IPG450)

7. National Institute for Clinical Excellence (2004) Stereotactic radiosurgery for trigeminal neuralgia using gamma knife. NICE interventional procedure guidance (IPG85)

8. Chou R, Fanciullo GJ, Fine PG et al. Clinical guidelines for the use of chronic opioid therapy in chronic noncancer pain. $J$ Pain 2009;10 (2):113-130 e22

9. Dillingham T, Pezzin L, MacKenzie E. Limb amputation and limb deficiencies: epidemiology and recent trends in the United States. SMJ. 2002; 95:875-883 
10. Ebrahimzadeh MH, Fattahi AS. Long-term clinical outcomes of Iranian veterans with unilateral transfemoral amputation. Disabil Rehabil. 2009; 31(22):1873-1877

11. Jensen TS, Krebs B, Nielsen J et al. Immediate and long-term phantom limb pain in amputees: incidence, clinical characteristics and relationship to pre-amputation limb pain. Pain. 1985; 21(2):267-278

12. Stokvis A, van der Avoort DJC, van Neck JW et al. Surgical management of neuroma pain: a prospective follow-up study. Pain. 2010; 151:862-869

13. Jung YJ, Park WY, Jeon JH et al. Outcomes of Ultrasound-guided extracorporeal shock wave therapy for painful stump neuroma. Ann Rehab Med. 2014; 38(4): 523-533

14. Bouroumand MR, Schulz D, Uhl E et al. Tibioperoneal Short Circuiting for stump neuroma pain in amputees: revival of an old technique. World Neurosurg. 2015; 84(3):681-687

15. Pet MA, Ko JH, Friedly JL, et al. Traction neurectomy for the treatment of painful residual limb neuroma in lower extremity amputees. J Orthop Trauma 2015; 29: e321-325

16. Pet MA, Ko JH, Friedly MD et al. Does targeted nerve implantation reduce neuroma pain in amputees? Clin Orthop Relat Res. 2014; 472:2991-3001

17. Balcin H, Erba P, Wettstein R et al. A comparative study of two methods of surgical treatment for painful neuroma. J Bone Joint Surg Br. 2009; 91(6): 803-808

18. Ducic I, Mesbahi AN, Attinger CE et al. The role of peripheral nerve surgery in the treatment of chronic pain associated with amputation stumps. JPRAS. 2008; 121:908-914

19. Sehirlioglu A, Ozturk C, Yazicioglu K et al. Painful neuroma requiring surgical excision after lower limb amputation caused by landmine explosions. Int Orthop. 2009; 33:533-536

20. Koch H, Hubmer M, Welkerling $\mathrm{H}$ et al. The treatment of painful neuroma on the lower extremity by resection and nerve stump transplantation into a vein. Foot Ankle Int. 2004; 25(7):476-481

21. Chiodo CP, Miller SD. Surgical treatment of superficial peroneal neuroma. Foot Ankle Int. 2004; 25(10):689-694 
22. Koch H, Haas F, Hubmer M et al. Treatment of Painful Neuroma by resection and nerve stump transplantation into a vein. Ann Plast Surg. 2003; 51:45-50

23. Barbera J, Albert-Pamplo R. Centrocenral anastomosis of the proximal nerve stump in the treatment of painful amputation neuromas of major nerves. J Neurosurg. 1993; 79:331-334

24. Martini A, Fromm B. A new operation for the prevention and treatment of amputation neuromas. J Bone Joint Surg Br. 1989; 71:379-382

25. Zeng Y, Wang X, Guo Y et al. Coblation of femoral and sciatic nerve for stump pain and phantom limb pain: a case report. Pain Prac. 2016; 16(2):E35-E41

26. Lim K, Kim Y, Kim J. Sonographically guided alcohol injection in painful stump neuroma. Ann Rehabil Med. 2012; 36:404-408

27. Gruber H, Glodny B, Bodner G et al. Practical experience with sonographically guided phenol instillation of stump neuroma: predictors of effects, success and outcome. Am J Roentgenol. 2008; 190:1263-1269

28. Neumann V, O'Connor R, Bush D. [Letters] DOI:10.2214/AJR.08.1371 Downloaded from www.ajronline.org. Available online only [accessed 31/2/2016]

29. Caporusso EF, Fallat LM, Savoy-Moore R. Cryogenic Neuroablation for the Treatment of Lower Extremity Neuromas. J Foot Ankle Surg. 2002; 41(5): 286-290

30. Kesikburun S, Yasar E, Dede I et al. Ultrasound-guided steroid injection in the treatment of stump neuroma: pilot study. J Back Musculoskelet Rehabil. 2014; 27:275-279

31. Kim WK, Jung I, Lee CH et al. Pulsed radiofrequency ablation under ultrasound guidance for huge neuroma. Korean J Pain. 2014; 27(3):290-293

32. Restrepo-Garces CE, Marinov A, McHardy P et al. Pulsed radiofrequency under ultrasound guidance for persistent stump-neuroma pain. Pain Prac 2011; 11(1):98-102

33. West $\mathrm{M}, \mathrm{Wu} \mathrm{H}$. Pulsed radiofrequency ablation for residual and phantom limb pain: a case series. Pain Prac. 2010; 10(5):485-491

34. Wilkes D, Ganceres N, Solanki D et al. Pulse radiofrequency treatment of lower extremity phantom limb pain. Clin J pain. 2008; 24(8):736-739 
35. Dellon AL, Mackinnon SE. Treatment of the painful neuroma by neuroma resection and muscle implantation. JPRAS. 1986; 44:427-438

36. Samii M. Centrocentral anastomosis of peripheral nerves. A neurosurgical treatment of amputation neuromas. Berlin, Heidelberg, New York; Springer; 1981

37. Vernadakis AK, Koch H, Mackinnon SE. Management of neuromas. Clin Plast Surg 2003; 30: $247-268$

38. Lewin-Kowalik J, Marcol W, Kotulska K et al. Prevention and Management of Painful neuroma. Neurol Med Chir (Tokyo) 2005; 46:62-68

39. Myers RR, Powell HC, Heckman HM et al. Biophysical and pathological effects of cryogenic nerve lesion. Ann Neurol. 1981; 10: 478-485

40. Pradel W, lawitschka M, Eckelt U et al. Cryosurgical treatment of genuine trigeminal neuralgia. Br J Oral Maxillofac Surg. 2002; 40: 244-247

41. Moorjani N, Zhao F, Tian Y et al. Effects of cryoanalgesia on post-thoracotomy pain and on the structure of intercostal nerves: a human prospective randomised trial and a histological study, Eur J Cardiothorac 2001; 20: 502-507

42. Speed CA, Extracorporeal shock-wave therapy in the management of chronic soft-tissue conditions. J Bone Joint Surg Br. 2004; 86:165-171

43. Chua NHL, Vissers KC, Sluijter ME. Pulsed radiofrequency treatment in interventional pain management: mechanisms and potential indications - a review. Acta Neurochir. 2010; $153: 763-771$

44. Laing T, Siddiqui A, Sood M. The management of neuropathic pain from neuromas in the upper limb: surgical techniques and future directions. JPRAS 2015; 2(4):165-170

45. Wu J, Chiu DTW. Painful neuromas: a review of treatment modalities. Ann Plast Surg. 1999; 43:661-667

46. Ramanavarapu V, Simopulos TT. Pulsed Radiofrequency of lumbar dorsal root ganglia for chronic post-amputation stump pain. Pain Physician 2008; 11:561-566

47. Xu S, Duan X, Yu X et al. The accuracy of ultrasonography and magnetic resonance imaging for the diagnosis of Morton's neuroma: a systematic review. Clin Radiol 2015; 70(4):351-358 
48. Freynhagen R, Baron R, Gocket $U$ et al. painDETECT: a new screening questionnaire to identify neuropathic components in pateitns with back pain. Curr Med Res Opin 2006; 22(10):1911-20

49. Benett M. The LANSS Pain Scale: the Leeds assessment of neuropathic symptoms and signs. Pain 2001; 92(1-2):147-157 


\begin{tabular}{|c|c|c|c|c|c|c|}
\hline \multicolumn{7}{|c|}{ Table 1: Surgical therapies } \\
\hline $\begin{array}{l}\text { Author } \\
\text { (Date) }\end{array}$ & Intervention & Outcomes & $\begin{array}{l}\text { Study } \\
\text { Design }\end{array}$ & Size & Results & Comments \\
\hline $\begin{array}{l}\text { Bourouman } \\
\text { d }(2015)^{14}\end{array}$ & $\begin{array}{l}\text { Nerve-to- } \\
\text { nerve } \\
\text { anastomosis } \\
\text { - "Centro- } \\
\text { central short } \\
\text { circuit" }\end{array}$ & $\begin{array}{l}\text { qVAS score } \\
\text { before and } \\
\text { after } \\
\text { interventio } \\
n \\
\text { Ability to } \\
\text { wear } \\
\text { prosthesis } \\
\text { Quality of } \\
\text { life } \\
\text { Medication }\end{array}$ & $\begin{array}{l}\text { Retrospectiv } \\
\text { e cohort (no } \\
\text { comparison } \\
\text { group) }\end{array}$ & $\begin{array}{l}8 \text { (6 AKA, } \\
2 \text { BKA) }\end{array}$ & $\begin{array}{l}\text { Mean } \\
\text { qVAS pre- } \\
\text { op: } 7.75 \pm \\
1.28 \\
\text { At follow- } \\
\text { up (mean } \\
6.8 \text { years): } \\
2.25 \pm 1.07\end{array}$ & $\begin{array}{l}\text { No comparison } \\
\text { group } \\
\text { Mann-Whitney U } \\
\text { test used for } \\
\text { significance in } \\
\text { addition to Wilcoxon } \\
\text { signed rank test } \\
\text { Small sample size } \\
\text { Confounding factor- } \\
\text { nerve stump also } \\
\text { buried into muscle } \\
\text { No mention as to } \\
\text { whether participants } \\
\text { had other types of } \\
\text { post-amputation pain } \\
\text { QoL measured as an } \\
\text { additional outcome } \\
\text { No reported post- } \\
\text { operative } \\
\text { complications }\end{array}$ \\
\hline $\begin{array}{l}\text { Pet } \\
(2015)^{15}\end{array}$ & $\begin{array}{l}\text { Traction } \\
\text { Neurectomy }\end{array}$ & $\begin{array}{l}\text { Pain (yes } \\
\text { or no) } \\
\text { following }\end{array}$ & $\begin{array}{l}\text { Retrospectiv } \\
\text { e case series }\end{array}$ & $\begin{array}{l}38(30 \\
\text { BKA, } 8 \\
\text { AKA })\end{array}$ & $\begin{array}{l}22 / 38 \\
(58 \%) \text { pain } \\
\text { free at }\end{array}$ & $\begin{array}{l}\text { Follow-up bias } \\
\text { Confounding factors } \\
\text { such as concomitant }\end{array}$ \\
\hline
\end{tabular}




\begin{tabular}{|c|c|c|c|c|c|c|}
\hline & & $\begin{array}{l}\text { traction } \\
\text { neurectomy } \\
? \\
\text { Secondary } \\
\text { outcome: } \\
\text { reoperation } \\
\text {, recurrent } \\
\text { symptomati } \\
\text { c neuroma }\end{array}$ & & & $\begin{array}{l}\text { follow-up } \\
\text { (mean } 37 \\
\text { months) }\end{array}$ & $\begin{array}{l}\text { pathologies that } \\
\text { could cause stump } \\
\text { pain not reported } \\
\text { Patients with } \\
\text { phantom limb pain } \\
\text { not recorded } \\
\text { Did not measure } \\
\text { ability to wear } \\
\text { prosthesis or QoL as } \\
\text { an outcome } \\
\text { Radiographic } \\
\text { imaging not used for } \\
\text { diagnosis or follow- } \\
\text { up } \\
\text { Other than treatment } \\
\text { failure, no other } \\
\text { complications were } \\
\text { mentioned }\end{array}$ \\
\hline $\begin{array}{l}\text { Pet (2014) } \\
16\end{array}$ & $\begin{array}{l}\text { Targeted } \\
\text { Nerve } \\
\text { Implantation }\end{array}$ & $\begin{array}{l}\text { Presence or } \\
\text { absence of } \\
\text { neuroma }\end{array}$ & $\begin{array}{l}\text { Retrospectiv } \\
\text { e Case } \\
\text { series }\end{array}$ & $\begin{array}{l}35(23 \\
\text { lower limb } \\
\text { amputation } \\
\text { s) }\end{array}$ & $\begin{array}{l}\text { Secondary } \\
\text { TNI, 20/23 } \\
(87 \%) \\
\text { were free } \\
\text { of neuroma } \\
\text { pain at } \\
\text { follow up } \\
(22 \\
\text { months, }\end{array}$ & $\begin{array}{l}\text { Included patients } \\
\text { with phantom pain } \\
\text { Minimum follow-up } \\
\text { time too short } \\
24 \% \text { lost to follow- } \\
\text { up } \\
\text { No radiological } \\
\text { imaging to aid } \\
\text { diagnosis of neuroma }\end{array}$ \\
\hline
\end{tabular}




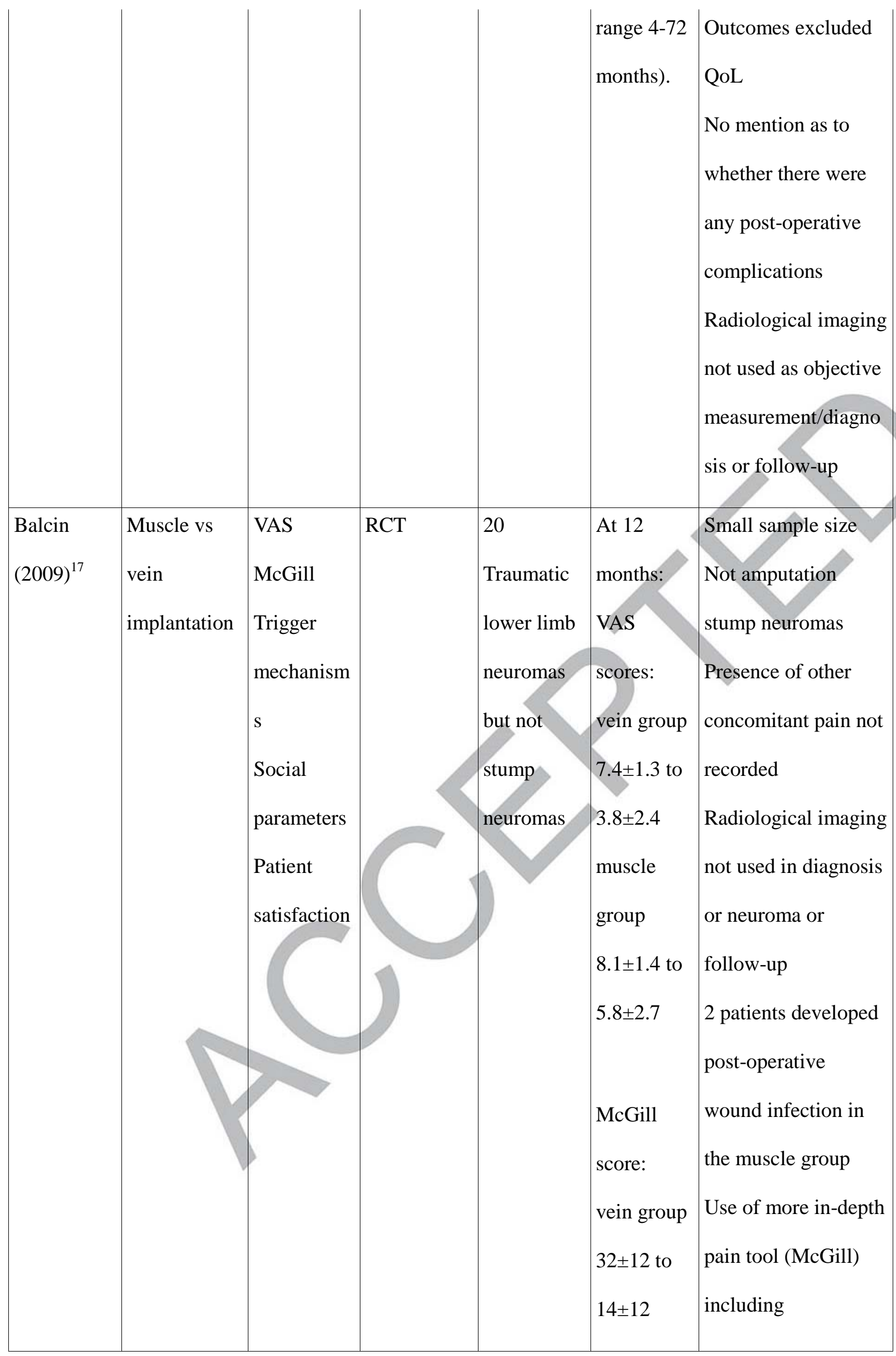




\begin{tabular}{|c|c|c|c|c|c|c|}
\hline & & & & & $\begin{array}{l}\text { muscle } \\
\text { group } \\
39 \pm 13 \text { to } \\
33 \pm 18\end{array}$ & $\begin{array}{l}\text { characteristic } \\
\text { description of pain }\end{array}$ \\
\hline $\begin{array}{l}\text { Ducic } \\
(2008)^{18}\end{array}$ & $\begin{array}{l}\text { Neurectomy } \\
\text { and muscle } \\
\text { implantation }\end{array}$ & $\begin{array}{l}\text { VAS scale } \\
\text { QoL } \\
\text { Ambulatio } \\
n \text { status } \\
\text { Absence of } \\
\text { spasms }\end{array}$ & $\begin{array}{l}\text { Retrospectiv } \\
\text { e cohort } \\
\text { with no } \\
\text { comparison } \\
\text { group }\end{array}$ & $\begin{array}{l}21(15 \\
\text { AKA/BKA } \\
\text { Remainder } \\
\text { UL } \\
\text { amputation }\end{array}$ & $\begin{array}{l}\text { Mean VAS } \\
\text { score } \\
\text { reduced } \\
\text { from } 8.04 \\
\pm 1.18 \text { to } \\
1.07 \pm 1.59 \\
\text { (p<0.0001) } \\
\text { at follow- } \\
\text { up (mean } \\
22.8 \\
\text { months) }\end{array}$ & $\begin{array}{l}\text { Assessor and } \\
\text { participant bias } \\
\text { Lack of control } \\
\text { group } \\
\text { Analysed a number } \\
\text { of outcomes } \\
\text { including QoL, } \\
\text { ability ot wear } \\
\text { prosthesis } \\
\text { Radiological imaging } \\
\text { not used in diagnosis } \\
\text { or as outcome } \\
\text { variable } \\
\text { No intraoperative or } \\
\text { post-operative } \\
\text { complications } \\
\text { reported }\end{array}$ \\
\hline $\begin{array}{l}\text { Sehirlioglu } \\
(2007)^{19}\end{array}$ & $\begin{array}{l}\text { Traction } \\
\text { Neurectomy }\end{array}$ & $\begin{array}{l}\text { Use of } \\
\text { prosthesis } \\
\text { Absence or } \\
\text { presence of }\end{array}$ & $\begin{array}{l}\text { Retrospectiv } \\
\text { e Case } \\
\text { series }\end{array}$ & $\begin{array}{l}75(52 \\
\text { BKA, } 23 \\
\text { AKA) }\end{array}$ & $\begin{array}{l}\text { All pain } \\
\text { free at } \\
\text { follow-up } \\
\text { mean } 2.8 \\
\text { years (6m- } \\
6 y)\end{array}$ & $\begin{array}{l}\text { No mention of pain } \\
\text { measurement tools } \\
\text { No detail of surgical } \\
\text { methodology } \\
\text { Low quality study } \\
\text { design }\end{array}$ \\
\hline
\end{tabular}




\begin{tabular}{|c|c|c|c|c|c|c|}
\hline & & $\begin{array}{l}\text { pain at } \\
\text { follow-up }\end{array}$ & & & $\begin{array}{l}\text { Pain tool } \\
\text { not } \\
\text { specified }\end{array}$ & $\begin{array}{l}\text { QoL not analysed } \\
\text { Wound dehiscence } \\
\text { reported in } 3 \text { patients } \\
\text { which was resolved } \\
\text { with revision surgery }\end{array}$ \\
\hline $\begin{array}{l}\text { Koch } \\
(2004)^{20}\end{array}$ & $\begin{array}{l}\text { Nerve stump } \\
\text { transplantatio } \\
\text { n into a vein }\end{array}$ & $\begin{array}{l}\text { Pain } \\
\text { (Herndon } \\
\text { 4-point } \\
\text { scale) } \\
\text { Interferenc } \\
\text { e with daily } \\
\text { activities } \\
\text { (5-point } \\
\text { scale) }\end{array}$ & $\begin{array}{l}\text { Retrospectiv } \\
\text { e case series }\end{array}$ & $\begin{array}{l}8 \text { (4 lower } \\
\text { limb } \\
\text { amputees; } \\
\text { level of } \\
\text { amputation } \\
\text { not } \\
\text { specified) }\end{array}$ & $\begin{array}{l}\text { 4/8 pain } \\
\text { free (grade } \\
\text { 1) and } 3 / 8 \\
\text { mild pain } \\
\text { at follow- } \\
\text { up (mean } \\
17\end{array}$ & $\begin{array}{l}\text { Mixture of amputees } \\
\text { and non-amputees } \\
\text { Small study } \\
\text { Did not look at QoL } \\
\text { No radiological } \\
\text { imaging used for } \\
\text { diagnosis or follow- } \\
\text { up } \\
\text { No complications } \\
\text { reported other than } \\
\text { recurrence of minor } \\
\text { pain at follow-up }\end{array}$ \\
\hline $\begin{array}{l}\text { Chiodo } \\
(2004)^{21}\end{array}$ & $\begin{array}{l}\text { Bone vs } \\
\text { muscle } \\
\text { implantation } \\
\text { for } \\
\text { superficial } \\
\text { peroneal } \\
\text { neuromas }\end{array}$ & $\begin{array}{l}\text { 10-point } \\
\text { verbal pain } \\
\text { analog } \\
\text { scale } \\
\text { Perceived } \\
\text { "percentage } \\
\text { relief" scale } \\
(0-100 \%)\end{array}$ & $\begin{array}{l}\text { Cohort (no } \\
\text { control) }\end{array}$ & $\begin{array}{l}\text { Group A: } \\
16 \\
\text { Group B: } \\
11\end{array}$ & $\begin{array}{l}\text { VAS score } \\
\text { and } \\
\text { perceived } \\
\% \text { of pain } \\
\text { relief } \\
\text { significantl } \\
\text { y better for } \\
\text { burial into }\end{array}$ & $\begin{array}{l}\text { Participants swapped } \\
\text { between groups } \\
\text { Concomitant } \\
\text { orthopaedic } \\
\text { procedures took } \\
\text { place } \\
\text { Small sample size } \\
\text { no lower limb }\end{array}$ \\
\hline
\end{tabular}




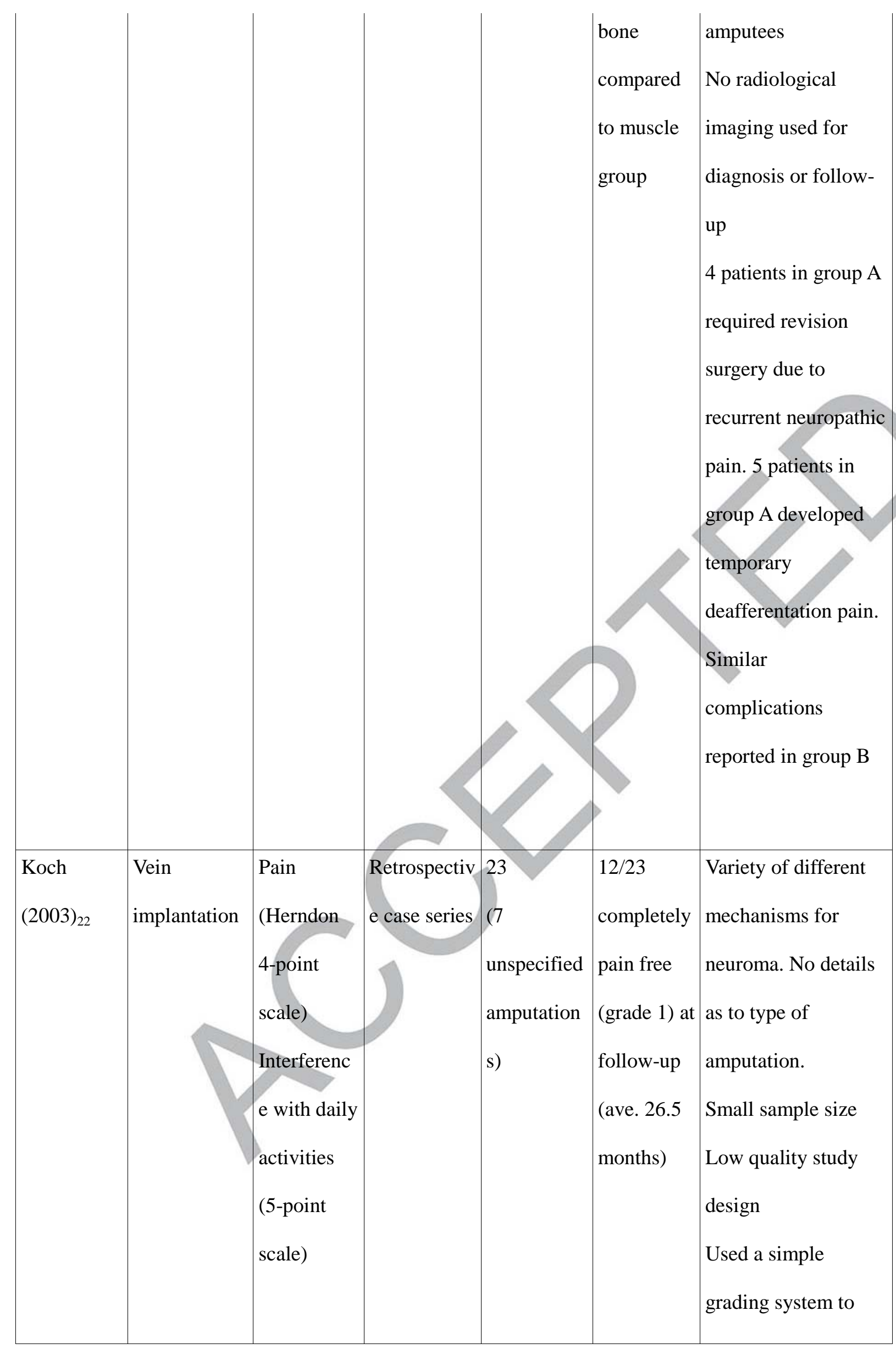




\begin{tabular}{|c|c|c|c|c|c|c|}
\hline & & & & & & $\begin{array}{l}\text { measure disability in } \\
\text { addition to pain } \\
\text { No radiological } \\
\text { imaging used for } \\
\text { diagnosis or follow- } \\
\text { up } \\
\text { No mention of any } \\
\text { complications }\end{array}$ \\
\hline $\begin{array}{l}\text { Barbera } \\
(1993)^{23}\end{array}$ & $\begin{array}{l}\text { Nerve-to- } \\
\text { nerve } \\
\text { anastomosis }\end{array}$ & $\begin{array}{l}\text { Absence of } \\
\text { neuroma } \\
\text { pain at } \\
\text { follow-up } \\
\text { Ability to } \\
\text { wear } \\
\text { prosthesis }\end{array}$ & Case series & $\begin{array}{l}22(20 \\
\text { AKA, } 2 \\
\text { BKA) }\end{array}$ & $\begin{array}{l}21 / 22 \\
\text { patients } \\
\text { had } \\
\text { complete } \\
\text { relief at } \\
\text { follow-up } \\
\text { (average } \\
\text { 15months) }\end{array}$ & $\begin{array}{l}\text { Moderate follow-up } \\
\text { time (mean } 15 \\
\text { months) } \\
\text { Pain measurement } \\
\text { tool not used } \\
\text { Phantom limb pain } \\
\text { not present in any } \\
\text { participants } \\
\text { No radiological } \\
\text { imaging used for } \\
\text { diagnosis or follow- } \\
\text { up } \\
\text { One patient had deep } \\
\text { local infection post- } \\
\text { operatively. } \\
\text { The same patient had } \\
\text { neuroma recurrence } \\
\text { anastamosis. }\end{array}$ \\
\hline
\end{tabular}




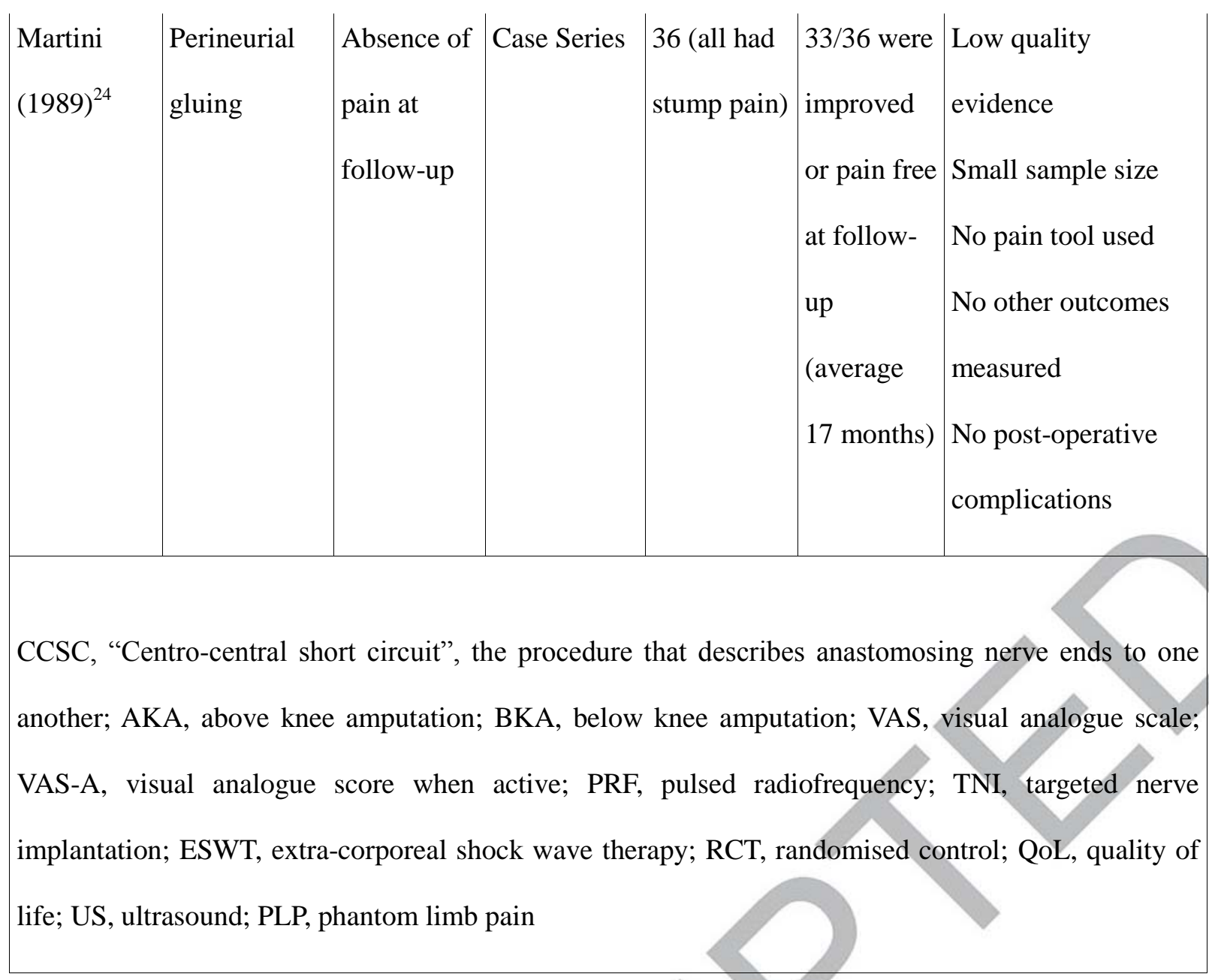

\begin{tabular}{|c|c|c|c|c|c|c|}
\hline \multicolumn{7}{|c|}{ Table 2: Neuroablative Therapies } \\
\hline $\begin{array}{l}\operatorname{Lim} \\
(2012)^{26}\end{array}$ & $\begin{array}{l}\text { Alcohol } \\
\text { injections }\end{array}$ & $\begin{array}{l}\text { Difference } \\
\text { in mean } \\
\text { VAS score }\end{array}$ & Case series & 2 AKA & $\begin{array}{l}\text { Some benefit. } \\
\text { Pain recurred } \\
\text { to some } \\
\text { degree after } \\
1^{\text {st }} \text { injection } \\
\text { VAS scores } \\
\text { Case } 1: 10 \text { to } \\
3 \\
\text { Case } 2: 8.5 \text { to }\end{array}$ & $\begin{array}{l}\text { Short follow-up time } \\
(3 \mathrm{~m}) \\
\text { Anecdotal, small } \\
\text { sample size } \\
\text { QoL or ability to use } \\
\text { prosthesis not } \\
\text { assessed } \\
\text { Use of ultrasound to } \\
\text { visualise neuroma }\end{array}$ \\
\hline
\end{tabular}




\begin{tabular}{|c|c|c|c|c|c|c|}
\hline & & & & & 4 & $\begin{array}{l}\text { but not used in } \\
\text { follow-up } \\
\text { No complications } \\
\text { reported }\end{array}$ \\
\hline $\begin{array}{l}\text { Gruber } \\
(2008)^{27}\end{array}$ & $\begin{array}{l}\text { Phenol } \\
\text { injections }\end{array}$ & $\begin{array}{l}\text { Pain } \\
\text { quantity } \\
\text { (VAS, 3- } \\
\text { point } \\
\text { scale) and } \\
\text { pain } \\
\text { quality } \\
\text { (character) }\end{array}$ & $\begin{array}{l}\text { Prospective } \\
\text { cohort }\end{array}$ & $\begin{array}{l}82 \text { (71 lower } \\
\text { limb, no } \\
\text { further } \\
\text { details) }\end{array}$ & $\begin{array}{l}\text { VAS score: } \\
\text { All patients } \\
10 \pm 1.5 \text { to } \\
3 \pm 2.6 \text { at } 6 \\
\text { months (ave } \\
\text { follow-up) } \\
7 / 52 \text { (13\%) } \\
\text { pain free at } \\
6 \mathrm{~m} \\
13 / 52 \text { almost } \\
\text { pain free } \\
10 \% \text { minor } \\
\text { complications }\end{array}$ & $\begin{array}{l}\text { Radiological imaging } \\
\text { (ultrasound) used as } \\
\text { part of diagnosis } \\
\text { No comparison } \\
\text { group } \\
\text { Poor participant } \\
\text { compliance making } \\
\text { some groups very } \\
\text { small size } \\
\text { Assessor bias } \\
5.8 \% \text { minor } \\
\text { complication rate } \\
\text { (painful oedema, } \\
\text { painful local } \\
\text { myopathy, local } \\
\text { infection) } \\
\text { Major complications } \\
\text { reported in } 1.3 \% \text { of } \\
\text { participants included } \\
\text { local soft-tissue } \\
\text { necrosis and } \\
\text { infectious erysipeloid }\end{array}$ \\
\hline
\end{tabular}




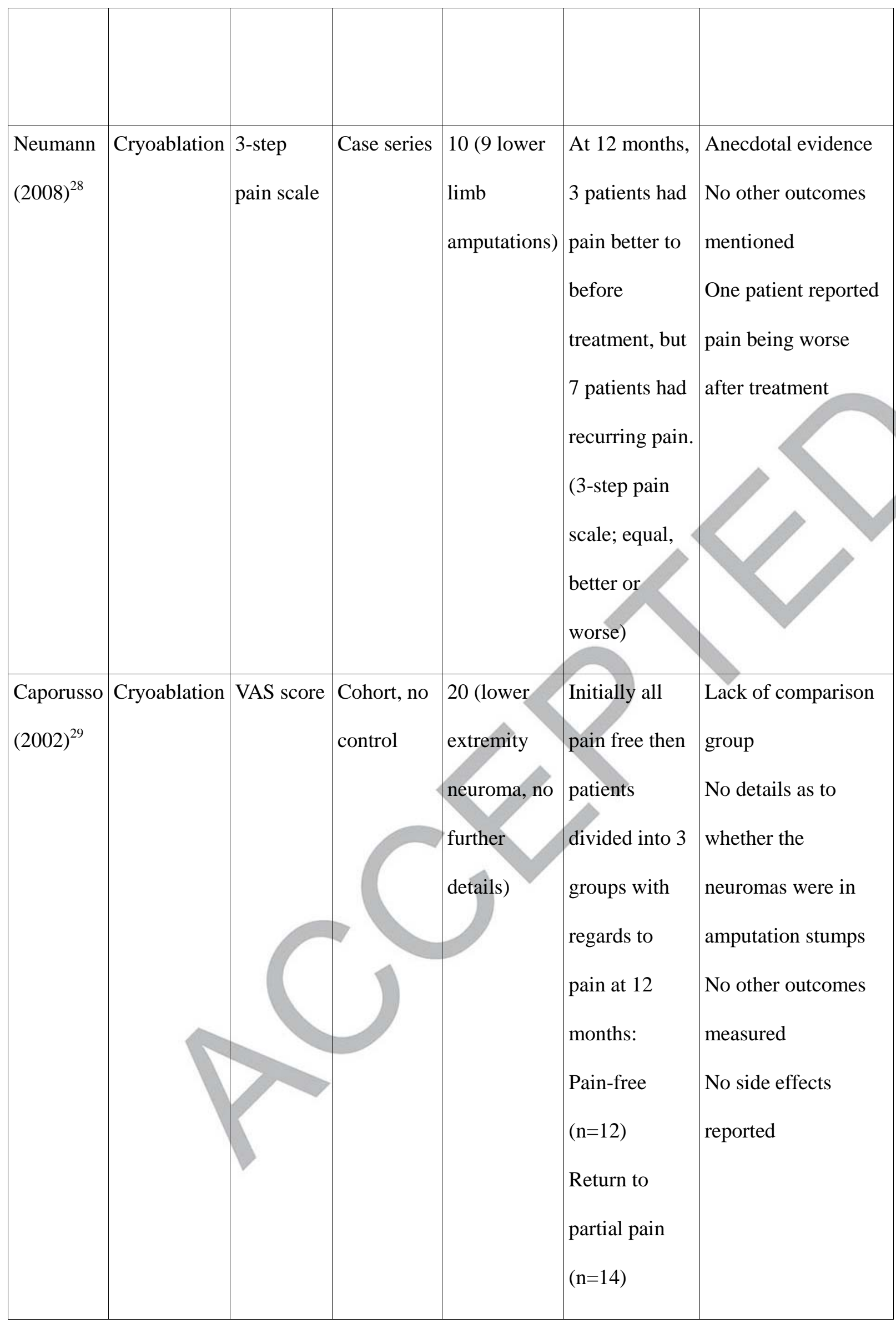




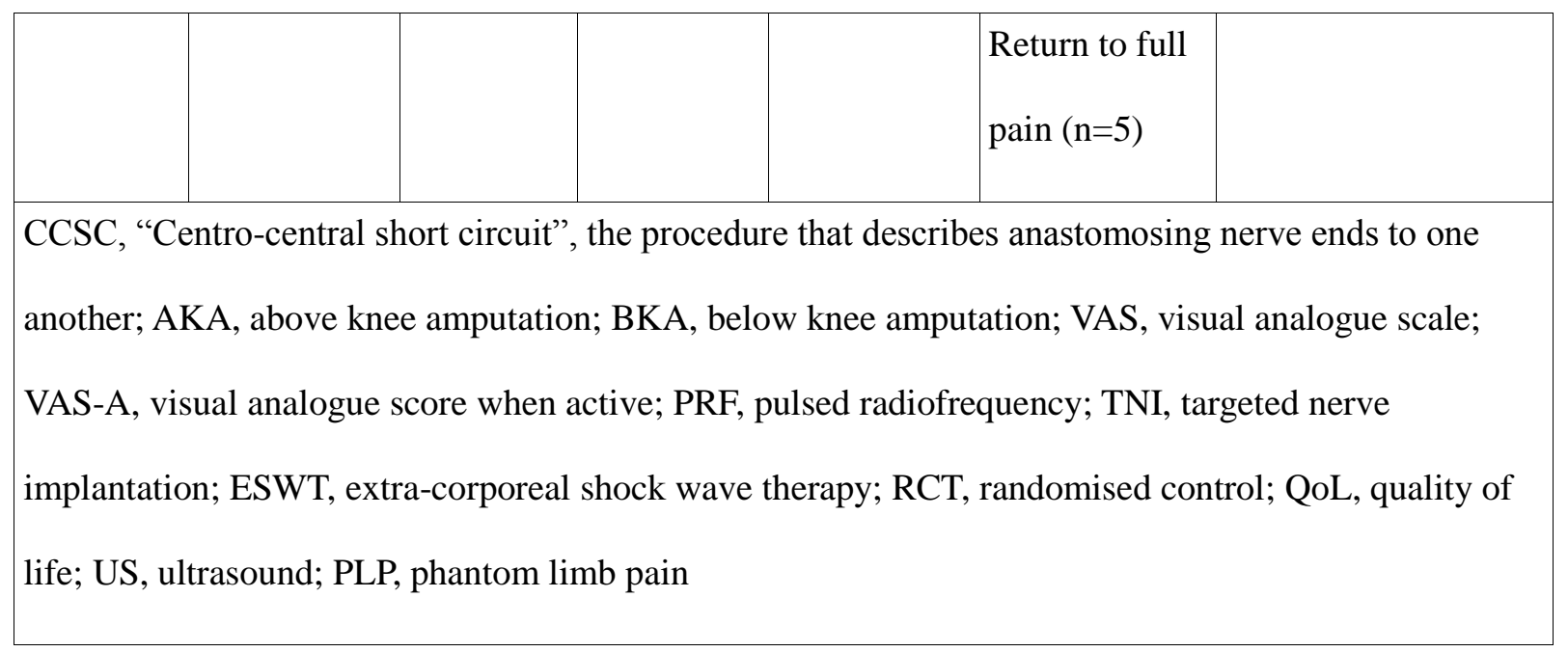

\begin{tabular}{|c|c|c|c|c|c|c|}
\hline \multicolumn{7}{|c|}{ Table 3: Other Therapies } \\
\hline $\begin{array}{l}\text { Kesikburun } \\
(2014)^{30}\end{array}$ & $\begin{array}{l}\text { Steroid } \\
\text { Injections }\end{array}$ & $\begin{array}{l}\text { 11-point } \\
\text { pain } \\
\text { scale }\end{array}$ & $\begin{array}{l}\text { Cohort } \\
\text { with no } \\
\text { control }\end{array}$ & $\begin{array}{l}14(12 \\
\text { BKA, } 2 \\
\text { AKA) }\end{array}$ & $\begin{array}{l}\text { Mean VAS score } \\
7.6 \text { to } 3.5 \text { where } \\
\text { wearing prosthesis } \\
\text { at } 6 \text { months. } 3 \\
\text { patients }\end{array}$ & $\begin{array}{l}\text { Small sample size } \\
\text { No comparison group } \\
\text { Short follow-up time } \\
\text { No mentions as to } \\
\text { whether there were any } \\
\text { complications } \\
\text { Used US imaging as aid } \\
\text { in diagnosing presence } \\
\text { of neuroma } \\
\text { Did not measure QoL }\end{array}$ \\
\hline $\begin{array}{l}\text { Jung } \\
(2014)^{13}\end{array}$ & $\begin{array}{l}\text { Shock } \\
\text { wave } \\
\text { therapy }\end{array}$ & $\begin{array}{l}\text { Pain } \\
\text { rating } \\
\text { scale - } \\
\text { resting } \\
\text { and }\end{array}$ & RCT & $\begin{array}{l}30 \text { stump } \\
\text { neuromas } \\
\text { (4 lower } \\
\text { limb } \\
\text { amputees) }\end{array}$ & $\begin{array}{l}\text { At final } \\
\text { assessment at } 3 \\
\text { months } \\
\text { McGill scores: } \\
\text { ESWT } 38.8 \pm 9 \text { to }\end{array}$ & $\begin{array}{l}\text { Used US in diagnosis } \\
\text { and follow-up } \\
\text { Short follow-up } \\
\text { Did not measure effects } \\
\text { on QoL }\end{array}$ \\
\hline
\end{tabular}




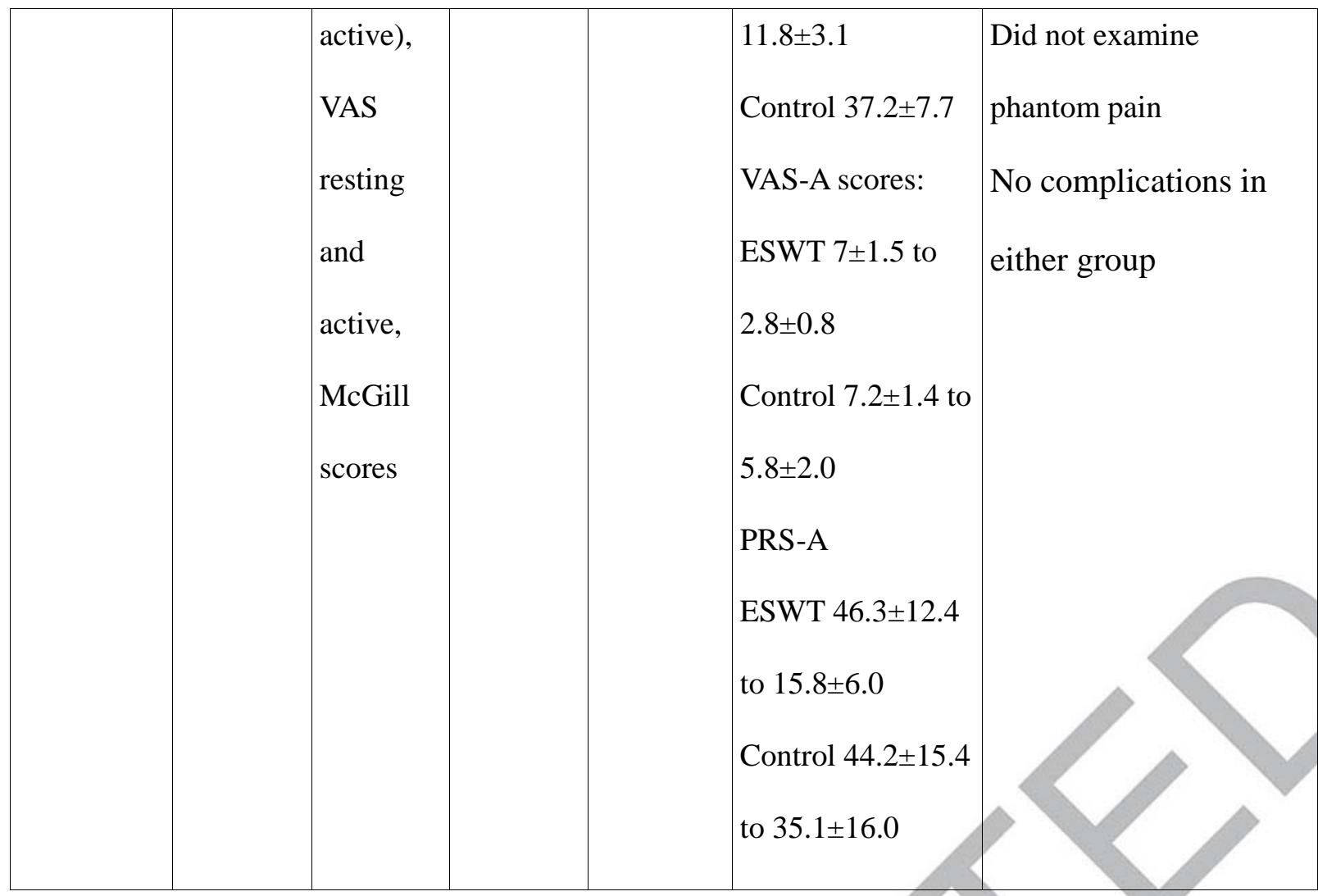

\section{Table 4: Radiofrequency treatments}

\begin{tabular}{|c|c|c|c|c|c|c|}
\hline $\begin{array}{l}\text { Zeng } \\
(2016)^{25}\end{array}$ & Coblation & VAS score & $\begin{array}{l}\text { Case } \\
\text { report }\end{array}$ & $1 \mathrm{AKA}$ & $\begin{array}{l}\text { Pain reduced } \\
\text { from } 8 / 10 \text { to } 2 / 10 \\
\text { at } 6 \mathrm{~m}\end{array}$ & $\begin{array}{l}\text { Anecdotal evidence } \\
\text { Examined the effects of } \\
\text { coblation on PLP } \\
\text { Used US imaging for } \\
\text { diagnosis and as therapy } \\
\text { aid } \\
\text { QoL improvement } \\
\text { briefly mentioned, not } \\
\text { formally assessed } \\
\text { No mention of } \\
\text { presence/ability to wear } \\
\text { prosthesis. }\end{array}$ \\
\hline
\end{tabular}




\begin{tabular}{|c|c|c|c|c|c|c|}
\hline & & & & & & $\begin{array}{l}\text { No complications } \\
\text { reported }\end{array}$ \\
\hline $\begin{array}{l}\text { Kim } \\
(2014)^{31}\end{array}$ & $\begin{array}{l}\text { Pulsed } \\
\text { radiofrequency }\end{array}$ & VAS score & $\begin{array}{l}\text { Case } \\
\text { report }\end{array}$ & $1 \mathrm{AKA}$ & $\begin{array}{l}\text { Decrease in VAS } \\
\text { for } 6 \text { months } \\
\text { during study } \\
\text { follow-up ( } 8.5 \text { to } \\
4.5 \text { when } \\
\text { wearing } \\
\text { prosthesis }\end{array}$ & $\begin{array}{l}\text { Anecdotal } \\
\text { Short follow-up } \\
\text { Used steroid injection in } \\
\text { addition to PRF } \\
\text { No mention of any } \\
\text { complications } \\
\text { No other outcomes } \\
\text { measured } \\
\text { No mention of } \\
\text { concomitant phantom } \\
\text { pain but stump pain } \\
\text { differentiated from } \\
\text { spinal stenosis with } \\
\text { EMG } \\
\text { US used for diagnosis } \\
\text { but not follow-up } \\
\text { Pain score on wearing } \\
\text { prosthesis improved }\end{array}$ \\
\hline $\begin{array}{l}\text { Restrepo- } \\
\text { Garces } \\
(2011)^{32}\end{array}$ & $\begin{array}{l}\text { Ultrasound } \\
\text { Guided Pulsed } \\
\text { radiofrequency }\end{array}$ & VAS score & $\begin{array}{l}\text { Case } \\
\text { report }\end{array}$ & $1 \mathrm{BKA}$ & $\begin{array}{l}\text { VAS score } \\
\text { reduced from } \\
10 \text { to } 3 \text { at } 6 \\
\text { months post } \\
\text { intervention }\end{array}$ & $\begin{array}{l}\text { Low quality evidence } \\
\text { Anecdotal } \\
\text { Ability to wear } \\
\text { prosthesis after } \\
\text { intervention mentioned }\end{array}$ \\
\hline
\end{tabular}




\begin{tabular}{|c|c|c|c|c|c|c|}
\hline & & & & & & $\begin{array}{l}\text { in results } \\
\text { US not used for follow- } \\
\text { up } \\
\text { No complications } \\
\text { occurred during follow- } \\
\text { up } \\
\text { QoL not analysed } \\
\text { No mention as to } \\
\text { whether phantom pain } \\
\text { was present }\end{array}$ \\
\hline $\begin{array}{l}\text { West } \\
(2010)^{33}\end{array}$ & $\begin{array}{l}\text { Ultrasound } \\
\text { Guided Pulsed } \\
\text { Radiofrequency }\end{array}$ & $\begin{array}{l}\text { VAS score, } \\
\text { ADLs, } \\
\text { ability to } \\
\text { wear } \\
\text { prosthesis } \\
\text { in painful } \\
\text { stump } \\
\text { neuroma, } \\
\text { analgesic } \\
\text { medications }\end{array}$ & $\begin{array}{l}\text { Case } \\
\text { series }\end{array}$ & $\begin{array}{l}4 \text { (all } \\
\text { BKA } \\
\text { or } \\
\text { AKA) }\end{array}$ & $\begin{array}{l}\text { All } 4 \text { were pain- } \\
\text { free or had } \\
\text { significant } \\
\text { improvement for } \\
\text { at least } 4 \text { months. } \\
\text { All } 4 \text { could wear } \\
\text { prosthesis } \\
\text { afterwards } \\
\text { VAS scores at } 6 \\
\text { months } \\
\text { Case one: } 9 \text { to } 4 \\
\text { Case two: } 8 \text { to } 0 \\
\text { Case three: } 8 \text { to } 3\end{array}$ & $\begin{array}{l}\text { Anecdotal evidence } \\
\text { Short follow-up time } \\
\text { Small sample } \\
\text { VAS not mentioned for } \\
\text { one case } \\
\text { No complications were } \\
\text { reported } \\
\text { QoL not analysed } \\
\text { Explored the effect on } \\
\text { phantom limb pain in } \\
\text { addition to stump pain. }\end{array}$ \\
\hline $\begin{array}{l}\text { Wilkes } \\
(2008)^{34}\end{array}$ & $\begin{array}{l}\text { Pulsed } \\
\text { radiofrequency }\end{array}$ & VAS score & $\begin{array}{l}\text { Case } \\
\text { report }\end{array}$ & $1 \mathrm{BKA}$ & $\begin{array}{l}\text { Patient was pain } \\
\text { free for } 4 \text { months }\end{array}$ & $\begin{array}{l}\text { Anecdotal } \\
\text { Case report }\end{array}$ \\
\hline
\end{tabular}




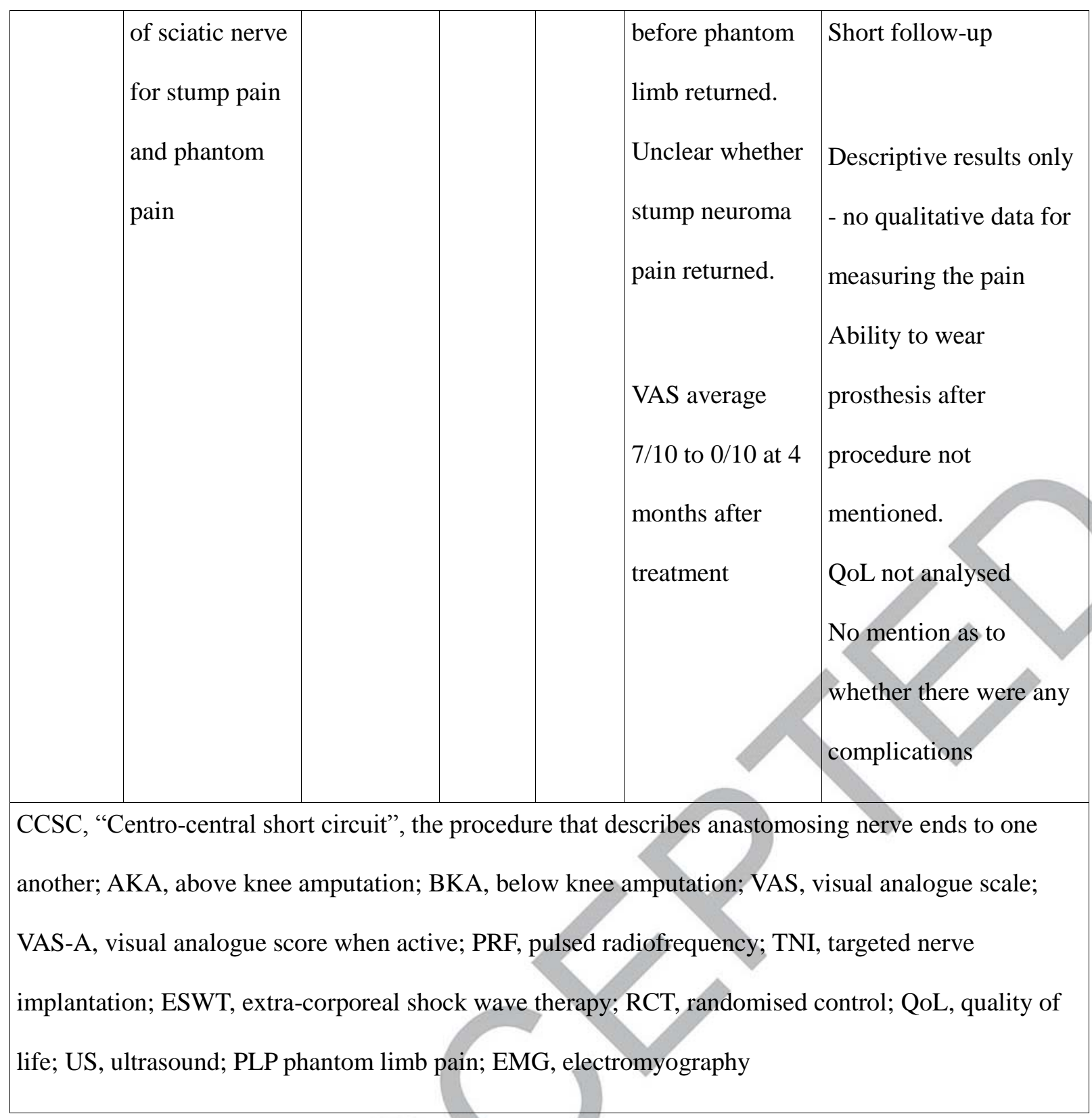

